\title{
Seasonal Changes in the Home Range and the Size of Harem Groups of Misaki Horses
}

\author{
Yujiro KASEDA \\ Faculty of Agriculture, Miyazaki University, \\ Miyazaki-shi 880
}

(Received September 13, 1982)

\begin{abstract}
The present investigation was carried out on the seasonal changes in the home range and the size of harem groups of Misaki horses in relation to the vegetation condition. Observations were made twice a month during the period from January, 1979 to December, 1981. In the breeding season, almost all harem groups usually lived with each group together on the grasslands covered with many kinds of grasses which were rich in both quality and quantity. After September when the grasslands tended to decrease in grass productivity, most of them generally separated into numerous, comparatively small groups based upon the strong social attachment; harem group consisting of one stallion and 2-3 particular mares or family group of one more and her offsprings, and transferred from the grasslands to the particular winter home range of their own in the forests or in the weedy grasslands, in which native grasses, forbs or trees were available for them during winter. No evidence of territorial behaviour was observed in Misaki horses during the study period, and the home ranges of different harem groups showed a great degree of overlap, especially in the breeding season.
\end{abstract}

Jpn. J. Zootech. Sci., 54 (4): 254-262, 1983

Horses commonly have the particular home ranges of their own to live and wander throughout the year, in which include a grazing area, one or more watering places and shelters ${ }^{1.2}$. Home ranges vary in size, depending on quality, quantity and availability of foods and water resourses ${ }^{3}$. Vegetation condition also varies over the season even where the range is of one plant community. Horses, therefore, often have separate winter and summer home ranges ${ }^{3)}$. Territoriality has been reported by KLINGEL ${ }^{4)}$ for wild zebras, but feral horses have not been observed to have territoriality, in which the geographic area is defended against other groups. Home ranges of feral horses commonly overlap or even coincide and the great deal of overlap are especially observed in summer ${ }^{6,6}$.

Misaki horses live in the wild-like states on Misaki pasture in Toi Cape of Miyazaki prefecture all the year round, forming various size of groups which change seasonally in composition ${ }^{7}$.

The present investigation was carried out on the seasonal changes in the home range and the size of harem groups of Misaki horses in relation to the vegetation condition in the pasture. 


\section{Materials and Methods}

Misaki horses totaled 73 including 8 stallions and 26 adult mares (above 3 years old) in 1979, 81 including 8 stallions and 24 adult mares in 1980 and 80 including 6 stallions and 34 adult mares in 1981, respectively.

The observations of behaviour of the horses were made twice a month during the period from January of 1979 to December of 1981. When horses were found, individual identification was made by natural coat color, sex, markings and the numbers branded on their hip. Individual number, the size and the composition of the group, the location of the horses, vegetation and foods on the site were recorded on sketch maps.

\section{Topography and Vegetation of the Pasture}

Komatsugaoka hill (287 $\mathrm{m}$ above the sea-level) and Ōgivama hill (295 $\mathrm{m}$ above the sea-level) stand in the center of the pasture (about $500 \mathrm{ha}$ ), and numerous small or large valleys run down in all directions from these hills. The pasture is divided into two areas by two large steep valleys rising from the border between two hills to southwest and to northeast. The west facing slope of Komatsugaoka hill and the south facing slope of Ōgiyama hill are relatively gentle, but the north and east facing

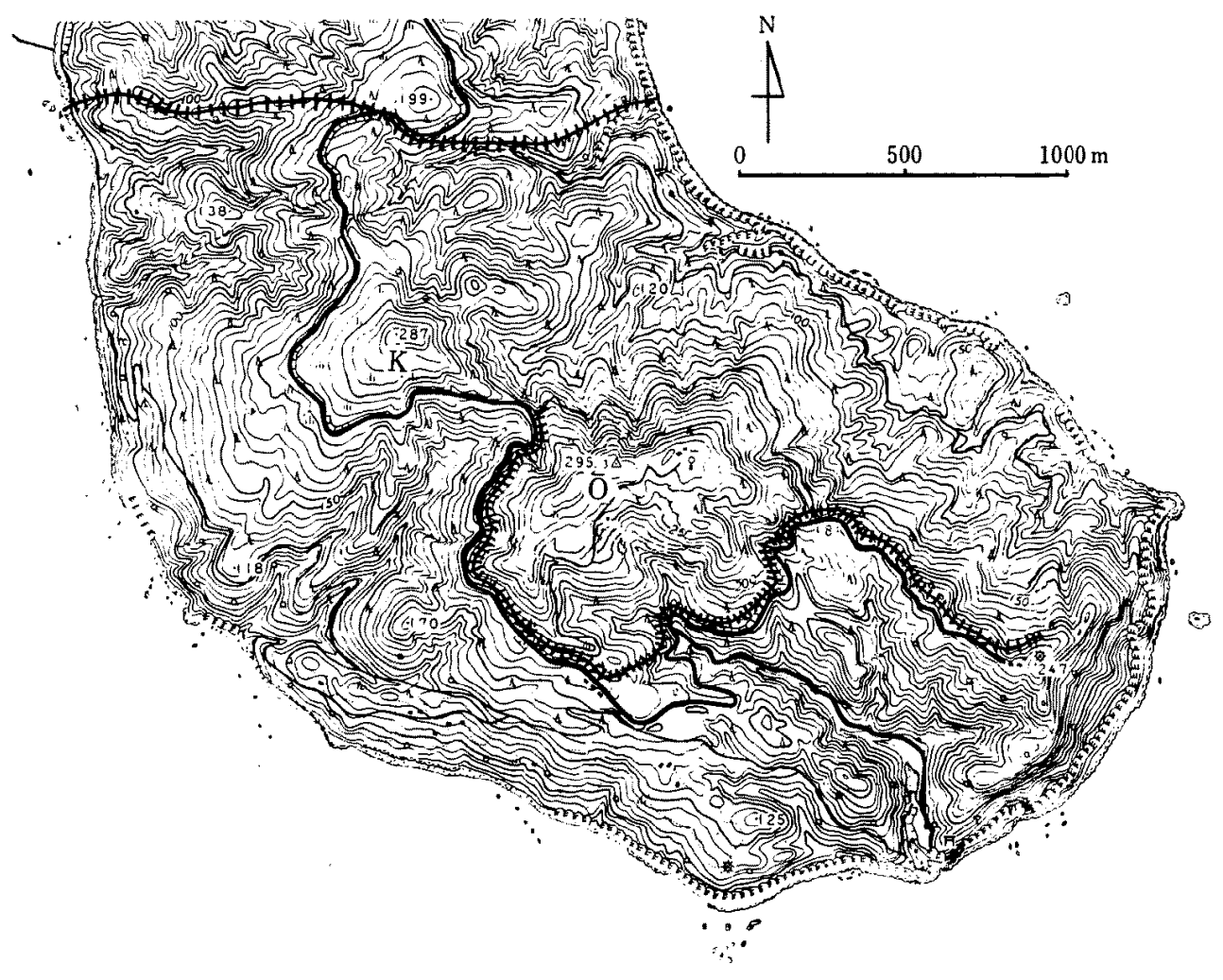

Fig. 1. Topography of Misaki pasture. A main road (black thick line) runs along the contour about $100 \mathrm{~m}$ above the sea-level. $\mathrm{K}$; Komatsugaoka hill, $\overline{\mathrm{O}}$; O giyama hill, H; Protection palings. 
slopes of these hills are markedly steep and complex in topography as shown in Fig. 1.

The land utilization and vegetation in the present pasture is shown in Fig. 2. Artificial forests of mainly Japanese ceder occupy about $50 \%$ of the pasture and main grasslands are restricted to the areas (accounted for $8 \%$ of the pasture) above the half way up two hills. The northeast forests of these hills are mostly covered with Japanese ceder over 16 years old and many kinds of copses, in which there are few grasses available for horses. On the other hand, there are many forests of young ceder under 15 years old on the west facing slope of Komatsugaoka hill and on the south facing slope of Ōgiyama hill, in which there are many kinds of native grasses and forbs available for horses in winter such as Miscanthus sinensis, Imperata cylindrica and Cyclosorus acuminatus. In addition, there are numerous small weedy grasslands including native grasses, fords and trees available for horses in winter such as Miscanthus sinensis, Pennisetum alopecuroides Pueraria lobata, Machilus thunbergii, Mallotus japonicus and Ilex rotunda along the southern beach of Ögiyama hill in Nakuhae.

The grasslands on Komatsugaoka and Ōgiyama hills are covered with Zosia japonica, Imperata cylindrica, Cyperus rotundus, Paspalum notatum, Paspalum orbiculare, Indigofera pseudo-tinctoria between March and October.

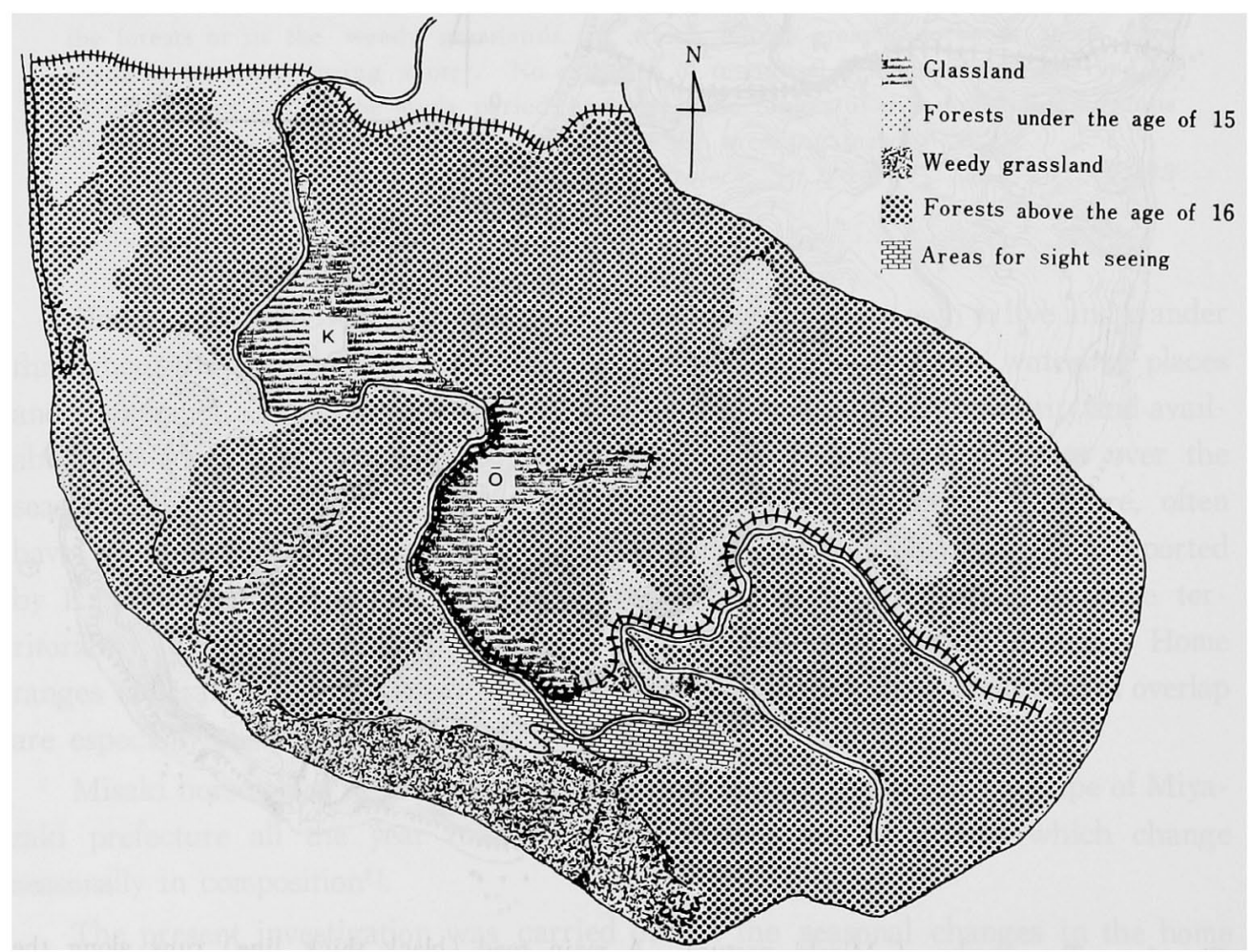

Fig. 2. The land utilization and the vegetation conditions in the pasture. $\mathrm{K}$; Komatsugaoka grassland, $\overline{0} ;$ Ōgiyama grassland. 


\section{Results and Discussion}

\section{Seasonal changes in the home range of harem groups}

Home ranges of stallion No. 37 and his member and stallion No. 18A and his member observed during the study period from 1979 to 1981 are shown in Fig. 3. Stallion No. 37 and his member (referred to hereafter as group 37) were always found to move together only on Komatsugaoka grassland in the breeding season from May to August, but they were often observed to transfer between the grassland and Kotani valley situated on the west of the grassland during late August-middle October and could hardly be found except in Kotani valley during winters of 1979 to 1980 . Stallion No. 18A and his member (referred to hereafter as group 18A) were always found to live together only on Komatsugaoka grassland during the period from April to August, but they were occasionally observed to live in the weedy grassland, in the forests of young ceder or on the roadside in Nakuhae located on the south of Ögiyama hill in winters of 1979 to 1981.

Home ranges of stallions Nos. 18B, 62 and 3 and their members observed in the

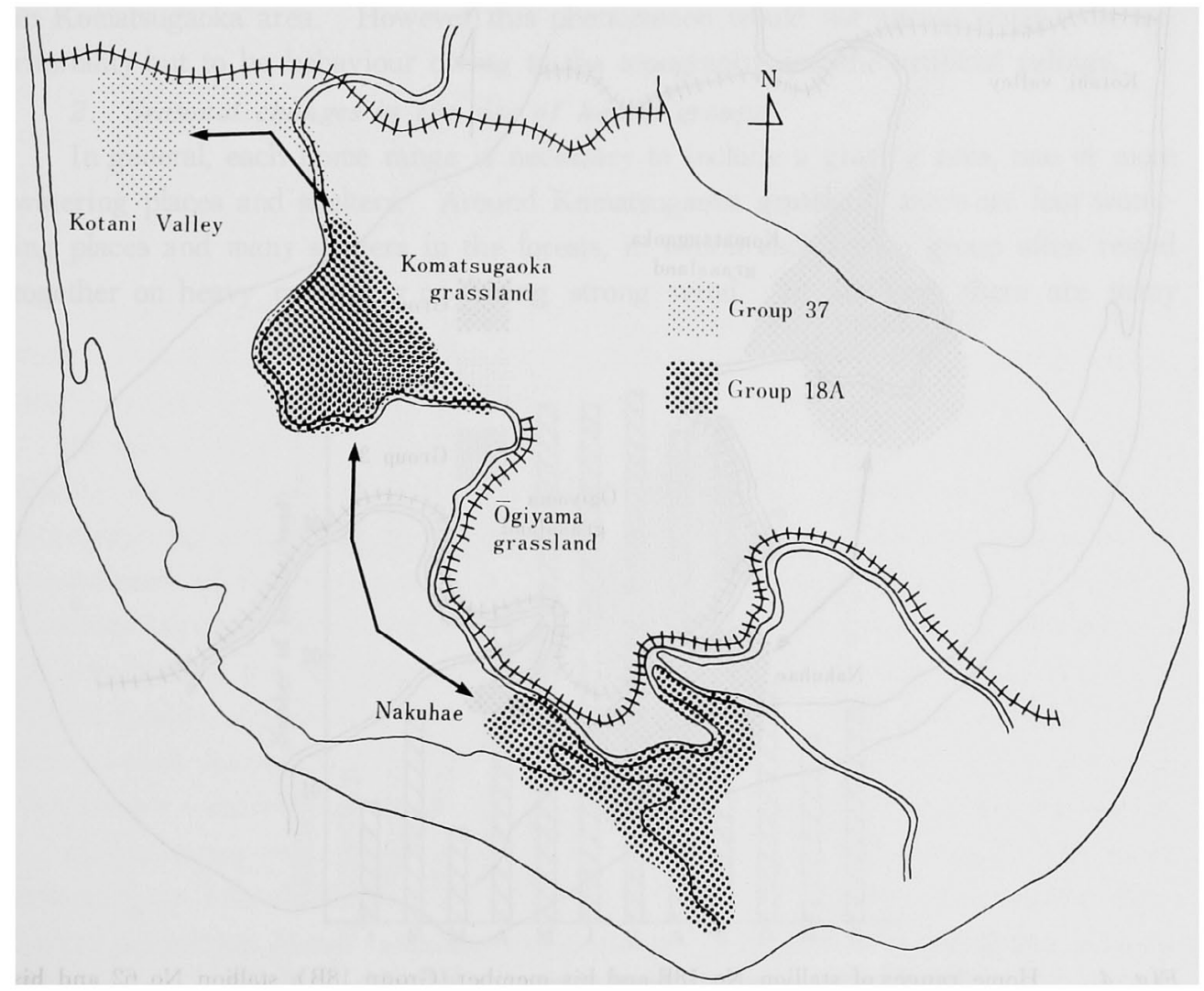

Fig. 3. Home ranges of stallion No. 37 and his member (Group 37) and stallion No. 18A and his member (Group 18A) observed during the study period from 1979 to 1981. 


\section{KASEDA}

study period are shown in Fig. 4. In the breeding season, stallion No. 18B and his member (group 18B) and stallion No. 62 and his member (group 62) were always seen to live with each group together only on Komatsugaoka grassland. In other season, however, group 62 wandered on the grassland, on the roadside or in the forests around the grassland. On the other hand, group $18 \mathrm{~B}$ were usually found to graze and rest on the weedy grassland or in the forests with young ceder in Nakuhae during winter.

The behavioural pattern of group $18 \mathrm{~B}$ was similar to that of group $18 \mathrm{~A}$, but there were some differences in the time of transference from the grassland to Nakuhae and in their home ranges in Nakuhae. Group 18A were often observed to transfer to Nakuhae during middle July-late August and to return to the grassland earlier than group $18 \mathrm{~B}$, but group $18 \mathrm{~B}$ were usually observed to transfer to Nakuhae during late September-early October and to return late April. Group 18A were occasionally found to live together in the eastern area of Nakuhae, but group $18 \mathrm{~B}$ usually spent in the western area. These two groups could not be found to live together in the same area.

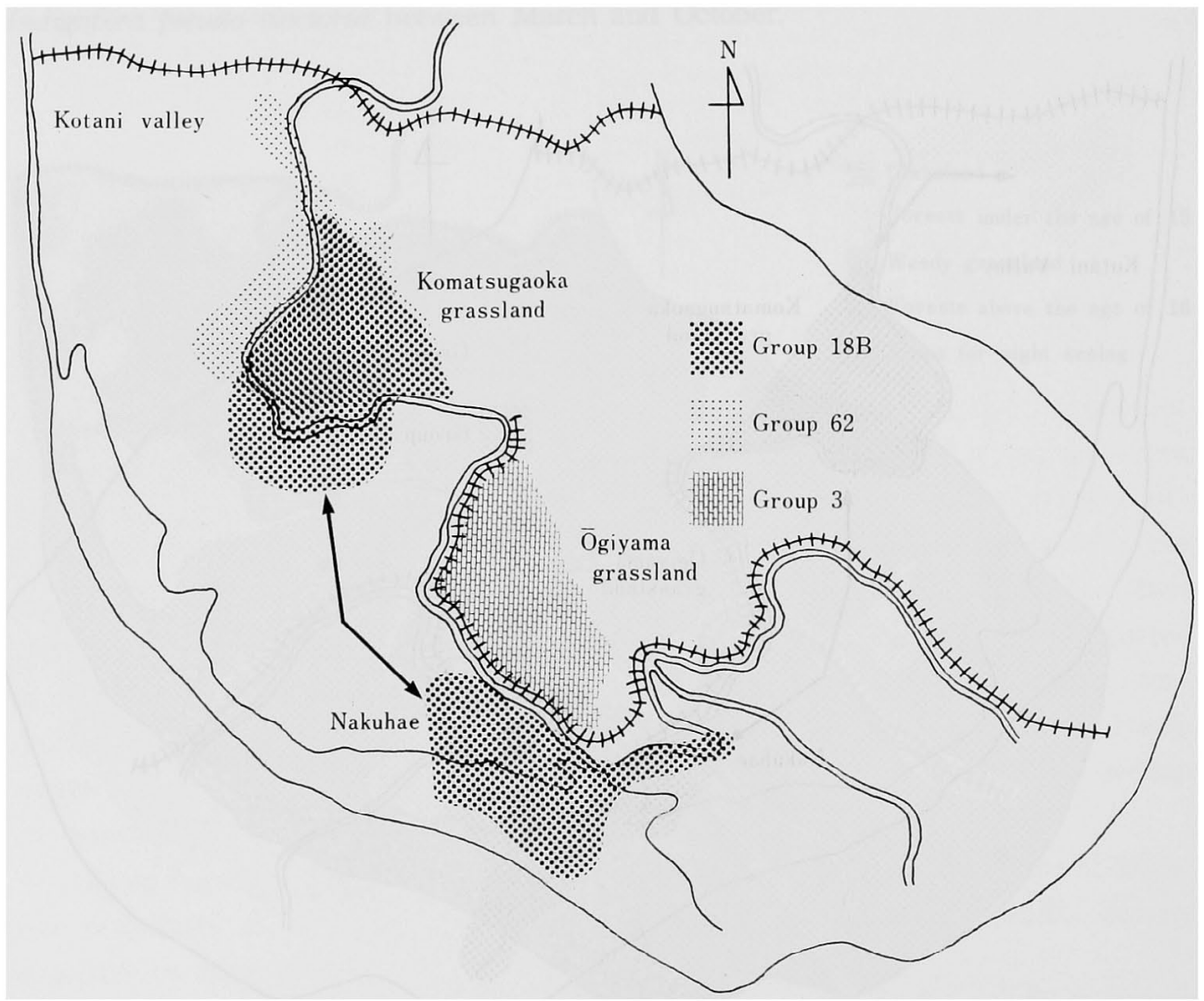

Fig. 4. Home ranges of stallion No. 18B and his member (Group 18B), stallion No. 62 and his member (Group 62) and stallion No. 3 and his member (Group 3) observed during the study period from 1979 to 1981. 
Stallion No. 3 and his member (group 3 ) were found to pass away on or around Oggiyama grassland all the year round, and could not be observed to move far from the grassland.

It has been reported by FeIsT and McCullovgh $^{5}$ that the Pryor Mountain horses were not territorial and a large overlap of home ranges by harems occurred. TYLER ${ }^{6)}$ has observed for New Forest Ponies that the home ranges of different groups freely overlapped and there were no monopolised zones especially in summer.

No evidence of territorial behaviour, in which the geographic area was defended against other groups, was observed in Misaki horses during the study period and the home ranges of different harem groups or other groups such as gelding groups showed a great degree of overlap, especially in the breeding season. The cases were often observed that one group moved to graze, followed by other groups on the same area on the grassland, although ImanisH has reported for Misaki horses to be territorial in $1950^{8)}$.

Long protection palings are equipped along the road from the border between two hills to the east end of pasture and two valleys sepa rated the pasture into two areas as mentioned before; Komatsugaoka area and Ōgiyama area. Therefore, the home ranges of horses living in Ōgiyama area were separated from those of horses living in Komatsugaoka area. However, this phenomenon would not always imply to be territoriality but to be behaviour owing to the topography and the artificial palings.

\section{Seasonal changes in the size of harem groups}

In general, each home range is necessary to include a grazing area, one or more watering places and shelters. Around Komatsugaoka grassland, there are four watering places and many shelters in the forests, in which each harem group often rested together on heavy rainy day or during strong wind. In addition, there are many

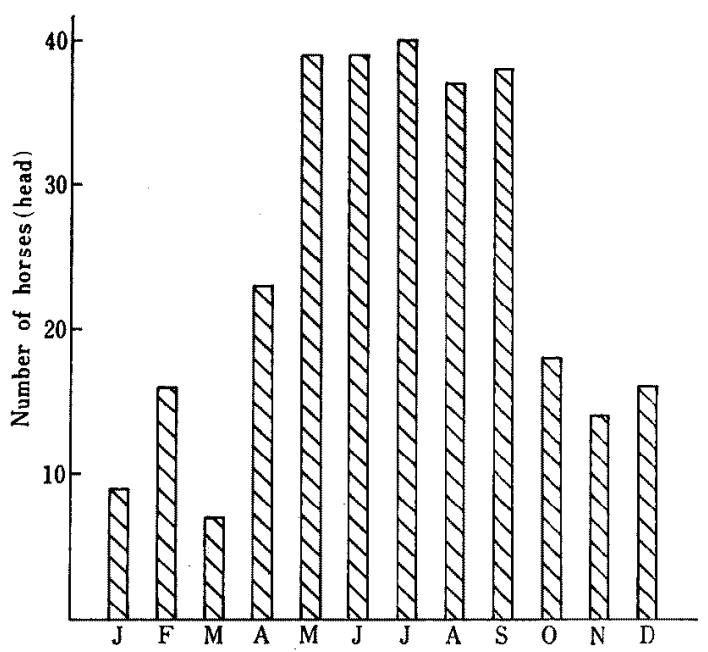

Fig. 5. Monthly changes in mean number of horses found on Komatsugaoka grassland throughout the day of each month from 1979 to 1981. 
kinds of grasses such as Zoysia japonica, Imperata cylindrica, Cyperus rotundus, Paspalum notatum and Paspalum orbiculare on this grassland. Since the yield of grasses available for horses totaled $7 \sim 8$ tons per hectare in the middle of August") and the grazing capacity of the grassland, postulated the herbage intake rate of $50 \%$, was estimated to be $2 \sim 3$ heads per hectare, this grassland (about 20 ha) was presumed to be able to support 40 60 adult horses from May to August. The productivity of the grassland showed a tendency to decrease gradually after September and the grazing capacity also decreased toward winter. The state of utilization of the grassland by horses can be understood in Fig. 5, in which the monthly changes in mean number of horses found on the grassland throughout the day of each month from 1979 to 1981 is given. On Komatsugaoka grassland, $4 \sim 5$ harem groups and some groups of $2 \sim 3$ geldings or $2 \sim 3$ colt foals were usually established and were found to graze and rest at the same time with each group together, totaling $38 \sim 40$ horses on the grassland in the breeding season.

Groups $18 \mathrm{~A}$ and $18 \mathrm{~B}$ transferred to Nakuhae during middle July-late August and during late September-early October, respectively. Group 37 also transferred to Kotani
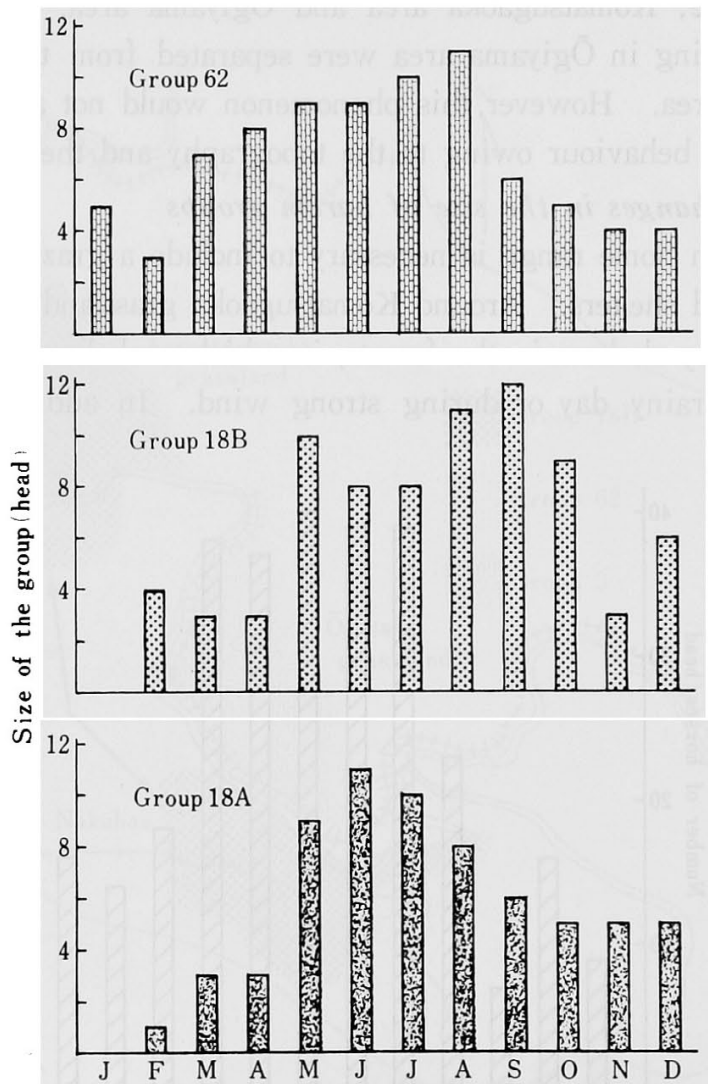

Fig. 6. Monthly changes in mean size of groups of stallions Nos. $62,18 \mathrm{~B}$ and $18 \mathrm{~A}$ found on the home ranges of their own throughout the day of each month from 1979 to 1981. Groups $18 \mathrm{~A}$ and $18 \mathrm{~B}$ could not be found in January. 
valley during late August-early October. Consequently, group 62, some colt foal groups and some pairs of a mare and her offsprings which had separated from their harem groups only remained on the grassland and the total number of horses on the grassland decreased.

Monthly changes in mean size of harem groups $62,18 \mathrm{~A}$ and $18 \mathrm{~B}$ found on their home ranges throughout the day of each month from 1979 to 1981 are given in Fig. 6. In general, each group increased in size during the period from May to August and decreased in other season. Group 62 lived on or around the grassland throughout the year, but since some pairs of a mare and her offsprings separated from the group and transferred to the winter home ranges of their own in the forests after September, the size of group 62 decreased in winter. These mares which had separated in the previous winter, however, usually returned with their new-born foals to the group from April to May, and the size of group 62 increased again in the breeding season. Group 18B consisted of stallion No. $18 \mathrm{~B}$ and 4 to 5 mares which continued foaling, and they usually lived together forming a large group on the grassland from May to September. However, this group were used to leave the grassland during the period from September to early October, and pass away in Nakuhae during winter. When the group leaved the grassland, $1 \sim 2$ pairs of a mare and her offsprings remained on the grassland or in the forests. In addition, almost all foals were occasionally observed to break away trom the group in winter. Consequently, group $18 \mathrm{~B}$ were found to live with consisting only stallion No. $18 \mathrm{~B}$ and $2 \sim 3$ mares in winter. Group $18 \mathrm{~A}$ increased in size in the same manner as in other harem groups during May-July, but when the group leaved the grassland, $2 \sim 3$ pairs of a mare and her offsprings separated from the group and spent in the home ranges of their own in winter. Consequently, the size of group 18A decreased in winter.

The observations on the social organization of these groups which developed in winter indicated that these groups were stable in membership by the social strong attachment between members, as shown by occasional mutual groomings.

Animals tend to seek for the microenvironment in which find themselves comfortable $^{2)}$. As mentioned before, Komatsugaoka and Ogiyama grasslands usually increased in grazing capacity during the period from May to August and became comfortable in microclimate for the life activities and the breedings of Misaki horses. Therefore, numerous horses could live together and each harem stallion could herd his harem on the grassland in the breeding season. However, since the grasses became to be poor in both quality and quantity and the grazing capacity tended to decrease after September, most horses were forced to transfer from the grassland to the other areas where there were enough foods for their winter lives in addition to water and shelter.

Misaki horses were usually observed to consume many kinds of native grasses or fords such as Miscanthus sinensis, Imperata cylindrica, Cyclosorus acuminatus, Farfugium japonicum, Pennisetum alopecuroides, Oplismenus undulatifolius, Rubus sieboldii and Pueraria lobata, and tree leaves such as Machilus thunbergii, Mallotus japonicus and Ilex rotunda as winter foods ${ }^{9.10)}$. Therefore, these kinds of native grasses, fords 
or trees are required in winter home ranges. Many areas which are met these requirements spread over the pasture, especially in the south-west areas of two hills. The space and grazing capacity of these areas, however, were too small for such large groups as observed during the breeding season to live together throughout winter. Therefore, Misaki horses were usually forced to separate into numerous small groups based on the social strong attachment; harem group consisting of one stallion and 2 3 particular mares or family group of a mare and her offsprings, and to transfer to the home ranges of their own to spend their winter lives.

It seems to be an adaptability of Misaki horses to the topography and vegetation condition on Misaki pasture to have separate winter and summer home ranges and to live together, forming comparatively small groups in the particular home ranges during winter.

It is estimated that these behaviour of Misaki horses may prove to be one of their behavioural adaptations to their habitats for long period of about 300 years.

\title{
References
}

1) Hafez, E. S. E., The Behaviour of Domestic Animals. 3rd. 355. Baillière Tindall. London. 1975.

2) Hafez, E. S. E., Adaptation of Domestic Animals. 202-214. Lea \& Febiger. Philadelphia. 1968.

3) Arnold, G. W. and M. L. Dudzinski, Ethology of free-ranging domestic animals. 84-89. Elsevier. New York. 1978.

4) Klingel, H., Zool. Anz. Suppl., 33: 311-316. 1969.

5) Feist, J. D. and D. R. McCullough, Z. Tierpsychol., 41: 337-371. 1976.

6) Tyler, S. J., Anim. Behav. Monogr., 5: 85-196. 1972.

7) Kaseda, Y., Jpn. J. Zootech. Sci., 52: 227-235. 1981.

8) Imanishi, K., Physiology and Ecology (Japanese), 4: 28-41. 1950.

9) Kurokt, M. and H. Ikeda, Bull. Fac. Agr. Miyazaki Uni., 315-322. 1974.

10) Kurokr, M., H. Ikeda, Y. Kaséda, and M. Hoshino, Bull. Fac. Agr. Miyazaki Uni., 22: 93-97. 1975 .

\section{御崎馬の Harem Group の行動圈及び群の 大きさの季節的変化}

\author{
加世田雄時朗
}

宮崎大学農学部，宮崎市 880

1979 年 1 月から 1981 年 12 月までの 3 年間, 御崎馬の harem group（1頭の種雄馬亡数頭の成此馬及びZの子 馬から構成された群) の行動圈と群の大きさの季節的变 化について，放牧地の植生との関連で調查した。

慗殖シーズンには，全ての harem group は, ノジ， チガヤ，ハマヌゲなどの馬の豬好する草が豊富に繁茂す る草地で生活した。この時期にはほとんど全ての成雌馬 はその子影とともに，それぞれ特定の harem groupに 加わるので，群の大きさは年間夲通じて最も大きくなっ た.しかし9月以降草地の生産量が減少し始めると, 大 部分の harem group は相に結びつきの強い馬同志の
小さな群に分れて草地を離れ，冬の主な採食草樹である ススキ，チガヤ，ホシダ、ッワブキなどの雑草やタブノ キ，アカメガシワ，クロガネモチなどの木の葉を求めて 15年以下の杉林内や海岸沿いの雑草地内のそれぞれ固有 の冬の行動圈に移動し，てこで冬を過した。

harem group の行動圈は相互に重複しており，特に繁 殖シーズンには多数の harem group が同じ草地を共有

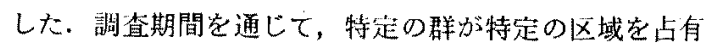
するいわ河るねねばり行動你認められなかった。

日蓄会報，54（4)：254-262，1983 